\title{
Long-term Remission of Cyclic Cushing's Disease that was Diagnosed and Treated Surgically in Non-active Phase
}

\author{
SHUICHIRO ASANO, HIKARU OOKA*, RYO OKAZAKI*, TOSHIO ISHIKAWA*, HIROMI OCHIAI*, \\ MichI NAKASHIMA, FUYUAKI IDE, ISAO HASEGAWA, SATORU MIYAWAKI, HIROSHI NAKAGUCHI, \\ MINEKO MURAKAMI, YOSHIO OGINO**, KOJI TAKANO*** AND AKIRA MATSUNO \\ Department of Neurosurgery, Teikyo University Chiba Medical Center, 3426-3 Anesaki, Ichihara City, Chiba 299-0111, Japan \\ *Department of Third Internal Medicine, Teikyo University Chiba Medical Center, 3426-3 Anesaki, Ichihara City, Chiba 299-0111, \\ Japan \\ **Department of Internal Medicine, Gengendo Kimitsu Hospital, 4-7-20 Higashisakata, Kimitsu City, Chiba 299-1144, Japan \\ ***Department of Nephrology and Endocrinology, University of Tokyo Hospital, 7-3-1 Hongo, Bunkyo-ku, Tokyo 113-0033, Japan
}

\begin{abstract}
Cyclic Cushing's disease is a rare clinical entity that is defined as a periodic excessive production of adrenocorticotropic hormone (ACTH) and cortisol. Only 42 cases with cyclic Cushing's disease have been reported in the literature. The diagnosis is very difficult because of the fluctuating secretion of ACTH and cortisol. We report a 78-yearold woman with a pituitary adenoma presenting with cyclic Cushing's disease. In the present case, several interesting issues are pointed out: 1) MRI study detected the presence of an adenoma and selective venous sampling in the cavernous sinus disclosed the hypersecretion of ACTH from a pituitary adenoma. These neuroimaging and endocrinological studies were helpful for the diagnosis, even in the remission phase. 2) The disease was in the long-term remission phase after transsphenoidal surgery despite the high recurrence rate in this clinical entity, although it recurred four years later. Even in the remission phase of cyclic Cushing's disease, meticulous endocrinological and neuroimaging examinations can reveal the presence of a pituitary adenoma, which should be treated surgically.
\end{abstract}

Key words: Cyclic Cushing's disease, ACTH, Cortisol, Pituitary adenoma

(Endocrine Journal 54: 407-412, 2007)

CYCLIC Cushing's disease is a rare clinical entity that is defined by an excessive production of adrenocorticotropic hormone $(\mathrm{ACTH})$ and cortisol in a regular cycle ranging from a few days to several months. Thus far, only 42 cases with cyclic Cushing's disease have been reported in the literature [1-37]. This rare condition has distinctive endocrinological characteristics that are different from overt Cushing's disease without cyclicity: 1) no suppression of cortisol by high dose administration of dexamethasone $[1-3,9-12,16,25] ; 2)$ blunted response of ACTH to an intravenous administration of corticotropin-releasing hormone (CRH) [15,

Received: December 20, 2006

Accepted: December 26, 2006

Correspondence to: Akira MATSUNO, M.D., Ph.D., Department of Neurosurgery, Teikyo University Chiba Medical Center, 3426-3 Anesaki, Ichihara City, Chiba 299-0111, Japan
17, 21, 22]; and 3) suppression of ACTH by bromocriptine [17, 19, 21, 22, 28]. Nevertheless, the diagnosis and surgical treatment of cyclic Cushing's disease are difficult. In this paper, we report a patient presenting with cyclic Cushing's disease, and discuss the diagnostic and surgical difficulties of this disease, with review on the literature.

\section{Case Report}

A 78-year-old woman presented with hypertension since 1997. She also presented with pretibial edema since 1998. In April, 1999, hypopotassemia (K $2.2 \mathrm{mEq} / \mathrm{l})$, depressive state and suicide attempt manifested, and she was admitted to a psychiatric hospital. In August, 1999, depressive state and pretibial edema spontaneously improved, and serum potassium con- 
Table 1. Endocrinological summary of the patient

\begin{tabular}{|c|c|c|c|c|c|c|c|c|c|}
\hline & \multicolumn{3}{|c|}{2000.2} & \multicolumn{3}{|c|}{2000.4 . } & \multicolumn{3}{|c|}{2000.6 . } \\
\hline & & $\begin{array}{l}2 \mathrm{mg} \\
\text { DEX }\end{array}$ & $\begin{array}{l}8 \mathrm{mg} \\
\text { DEX }\end{array}$ & & $\begin{array}{l}\text { basal/ } \\
\text { CRH }\end{array}$ & $\begin{array}{l}\text { peak/ } \\
\text { CRH }\end{array}$ & & $\begin{array}{c}\text { basal/ } \\
\text { CRH }\end{array}$ & $\begin{array}{l}\text { peak/ } \\
\text { CRH }\end{array}$ \\
\hline Urinary17-OHCS (3.4-12.0 mg/day) & 51.3 & 38.5 & 20.7 & & & & 7 & & \\
\hline Urinary free cortisol $(11.2-80.3 \mu \mathrm{g} /$ day $)$ & 3029 & 1896 & 598 & & & & $106.8-172.4$ & & \\
\hline plasma ACTH $(7-56 \mathrm{pg} / \mathrm{ml})$ & 72 & 97 & 90 & $139-160.4$ & 139 & 179.7 & $18.2-52.6$ & 30 & 171.4 \\
\hline serum cortisol $(4-18.3 \mu \mathrm{g} / \mathrm{dl})$ & 38.9 & 49.4 & 50 & $76-80$ & 76 & 92 & $11.5-14.2$ & 11.5 & 23.5 \\
\hline serum K (3.5-5.3 mEq/1) & \multicolumn{3}{|c|}{1.7} & \multicolumn{3}{|c|}{3.7} & \multicolumn{3}{|c|}{4.4} \\
\hline eosinocyte $(0.0-7.0 \%)$ & & & & \multicolumn{3}{|c|}{0} & \multicolumn{3}{|c|}{0.8} \\
\hline phase & \multicolumn{3}{|c|}{ active } & \multicolumn{3}{|c|}{ active } & \multicolumn{3}{|c|}{ remission } \\
\hline
\end{tabular}

\begin{tabular}{|c|c|c|c|c|c|c|c|c|}
\hline & \multirow{2}{*}{$\begin{array}{c}2000.8 \\
\text { postop }\end{array}$} & \multirow[b]{2}{*}{2000.9 . } & \multicolumn{5}{|c|}{2001.2.} & \multirow[b]{2}{*}{2004.11.} \\
\hline & & & & $\begin{array}{l}\text { basal/ } \\
\text { CRH }\end{array}$ & $\begin{array}{l}\text { peak/ } \\
\text { CRH }\end{array}$ & $\begin{array}{c}\mathrm{O} / \mathrm{N} \text { DEX } \\
1 \mathrm{mg}\end{array}$ & $\begin{array}{c}\mathrm{O} / \mathrm{N} \text { DEX } \\
8 \mathrm{mg}\end{array}$ & \\
\hline Urinary17-OHCS (3.4-12.0 mg/day) & & & 4 & & & & & \\
\hline Urinary free cortisol $(11.2-80.3 \mu \mathrm{g} /$ day $)$ & & & 56.6 & & & & & \\
\hline plasma ACTH $(7-56$ pg/ml) & 34.8 & & 45.8 & 43.7 & 79 & 15.7 & 11.2 & 242 \\
\hline serum cortisol $(4-18.3 \mu \mathrm{g} / \mathrm{dl})$ & 17.5 & 8.1 & & 7.5 & 12.9 & 1.3 & 1.7 & 92.6 \\
\hline serum $\mathrm{K}(3.5-5.3 \mathrm{mEq} / \mathrm{l})$ & 4.2 & 3.8 & \multicolumn{5}{|c|}{4.3} & 1.2 \\
\hline eosinocyte $(0.0-7.0 \%)$ & 2.2 & 1.1 & \multicolumn{5}{|c|}{3.2} & 0 \\
\hline phase & remission & remission & \multicolumn{5}{|c|}{ remission } & active \\
\hline
\end{tabular}

17-OHCS: 17-hydroxycorticosteroid

ACTH: adrenocorticotropic hormone

DEX: dexamethasone

$\mathrm{CRH}$ : corticotropin-releasing hormone

centration was normalized (K $4.3 \mathrm{mEq} / \mathrm{l})$. In February, 2000, depressive state, along with edema and hypopotassemia (K $1.7 \mathrm{mEq} / \mathrm{l})$, manifested again. Then the patient was admitted to Gengendo Kimitsu Hospital. As shown in Table 1, blood chemistry revealed elevated levels of plasma ACTH of $72 \mathrm{pg} / \mathrm{ml}$ (normal range: $7-56 \mathrm{pg} / \mathrm{ml}$ ) and serum cortisol of $38.9 \mu \mathrm{g} / \mathrm{dl}$ (4$18.3 \mu \mathrm{g} / \mathrm{dl}$ ). Urinary 17-hydroxycorticosteroid (17OHCS) and free cortisol levels were $51.3 \mathrm{mg} /$ day (3.4$12.0 \mathrm{mg} /$ day) and $3029 \mu \mathrm{g} /$ day $(11.2-80.3 \mu \mathrm{g} /$ day). These elevated values of urinary 17-OHCS and free cortisol were not suppressed to normal range by administration of $2 \mathrm{mg}$ /day dexamethasone for 2 days or by $8 \mathrm{mg} /$ day dexamethasone for 2 days. Magnetic resonance imaging (MRI) revealed a pituitary adenoma. Based on these endocrinological and neuroimaging examinations, the patient was suspected to have cyclic Cushing's disease, and referred to Teikyo University Chiba Medical Center in April, 2000. She had no habit of alcohol drinking.

Physical examination revealed thinning of skin and edematous extremities, without characteristic Cushingoid features including central obesity and moon face. Blood chemical examination revealed elevated levels of plasma ACTH of $139-160.4 \mathrm{pg} / \mathrm{ml}$ and serum cortisol of 76-80.0 $\mu \mathrm{g} / \mathrm{dl}$. Percentage of eosinocyte (Eo) in white blood cell (WBC) count was 0\%. Diurnal rhythm of ACTH and cortisol was lost. After CRH stimulation, basal/peak plasma ACTH and serum cortisol values were $139 / 179.7 \mathrm{pg} / \mathrm{ml}$ (30 $\mathrm{min})$, and 76/ $92 \mu \mathrm{g} / \mathrm{dl}(60 \mathrm{~min})$, respectively. The patient had pneumonia and urinary tract infection that was treated medically. In June, 2000, after CRH stimulation, basal/ peak plasma ACTH and serum cortisol values were 30/ $171.4 \mathrm{pg} / \mathrm{ml}(30 \mathrm{~min})$, and $11.5 / 23.5 \mu \mathrm{g} / \mathrm{dl}(60 \mathrm{~min})$, respectively. Urinary $17-\mathrm{OHCS}$ and free cortisol were $7 \mathrm{mg} /$ day and $106.8-172.4 \mu \mathrm{g} /$ day, which were remarkably reduced, compared with the values in February, $2000(51.3 \mathrm{mg} / \mathrm{day}$ and $3029 \mu \mathrm{g} /$ day $)$. Plasma ACTH and serum cortisol levels were reduced to 18.2 $52.6 \mathrm{pg} / \mathrm{ml}$ and $11.5-14.2 \mu \mathrm{g} / \mathrm{dl}$. Serum potassium level was also normalized (K 3.7-4.4 mEq/l). Percentage 

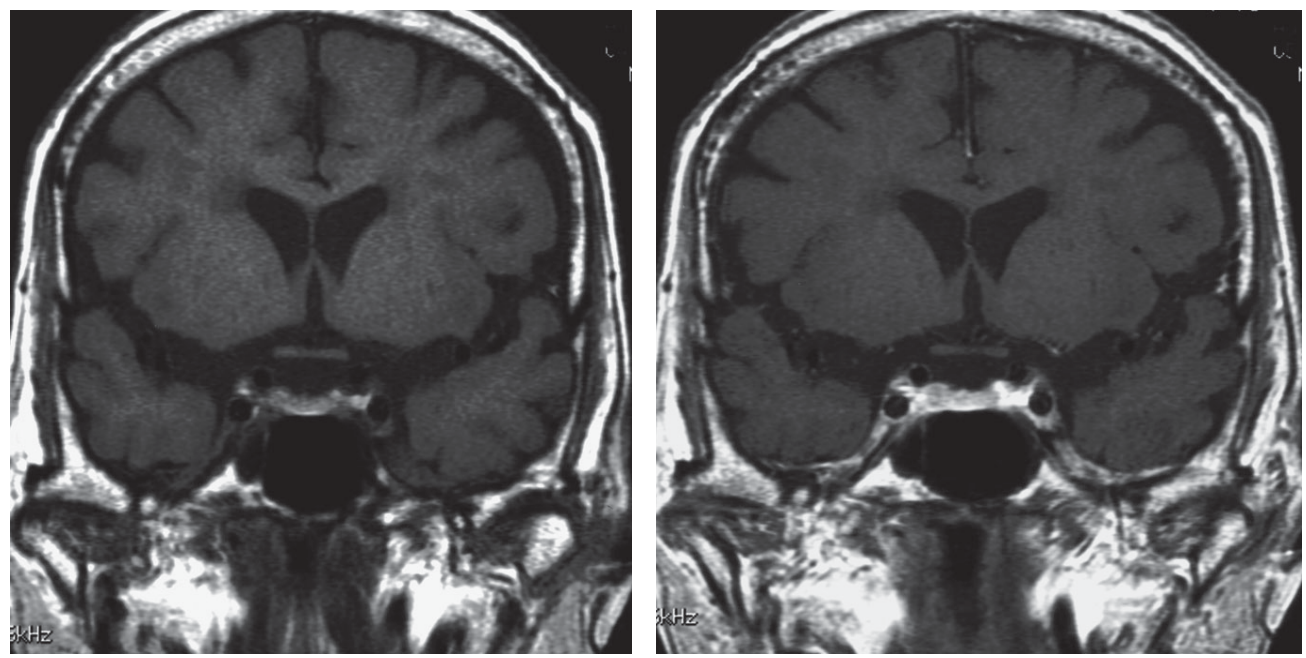

Fig. 1. T1-weighted MRI revealed a low signal intensity lesion (left) with less enhancement (right) in the right half of the pituitary gland, which suggested a pituitary adenoma (coronal section).
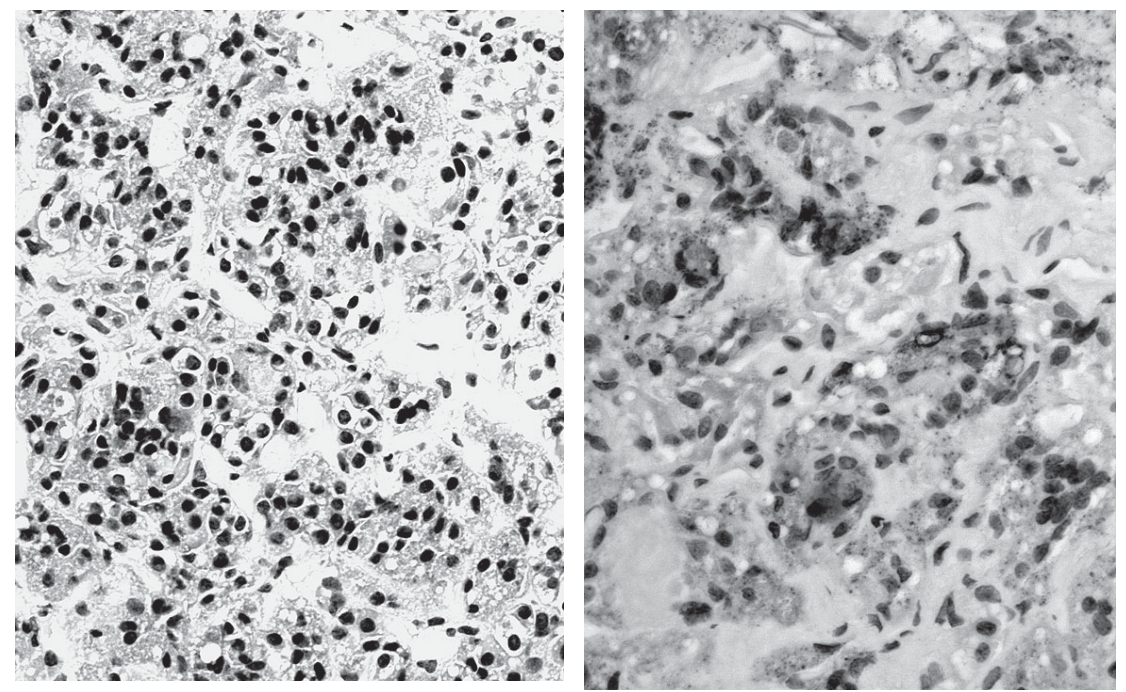

Fig. 2. Histopathological examination with hematoxylin-eosin staining confirmed the tumor as a chromophobe pituitary adenoma (original magnification $\times 200$, left). Immunohistochemical staining revealed ACTH-immunopositive cells (original magnification $\times 200$, right).

of Eo in WBC count was $0.8 \%$. These endocrinological studies revealed the remarkable normalization of ACTH-cortisol axis. T1-weighted MRI disclosed a less enhanced lesion in the right half of the pituitary gland (Fig. 1), and selective venous sampling in the right cavernous sinus revealed high value of $\mathrm{ACTH}$ (440.5 pg/ml) compared with peripheral plasma ACTH level (37.1 pg/ml) (central/peripheral ratio 11.9).

Transsphenoidal surgery was carried out on August 24, 2000 , and the tumor in the pituitary gland was removed. Histopathological examination with hematoxylin-eosin staining confirmed the tumor as a chromophobe pituitary adenoma (Fig. 2-a), and immunohistochemical staining revealed ACTH-immunopositive cells (Fig. 2b). Postoperative basal levels of plasma ACTH and serum cortisol were $34.8 \mathrm{pg} / \mathrm{ml}$ and $17.5 \mu \mathrm{g} / \mathrm{dl}$, respectively. Postoperative cortisol level was not suppressed but was within normal range, suggesting that the surgical procedure controlled hypersecretion of ACTH, but failed to extirpate the ACTH-secreting adenoma cells. Serum potassium level was $4.2 \mathrm{mEq} / 1$, and percentage of Eo in WBC count was $2.2 \%$. Other endocrinological 

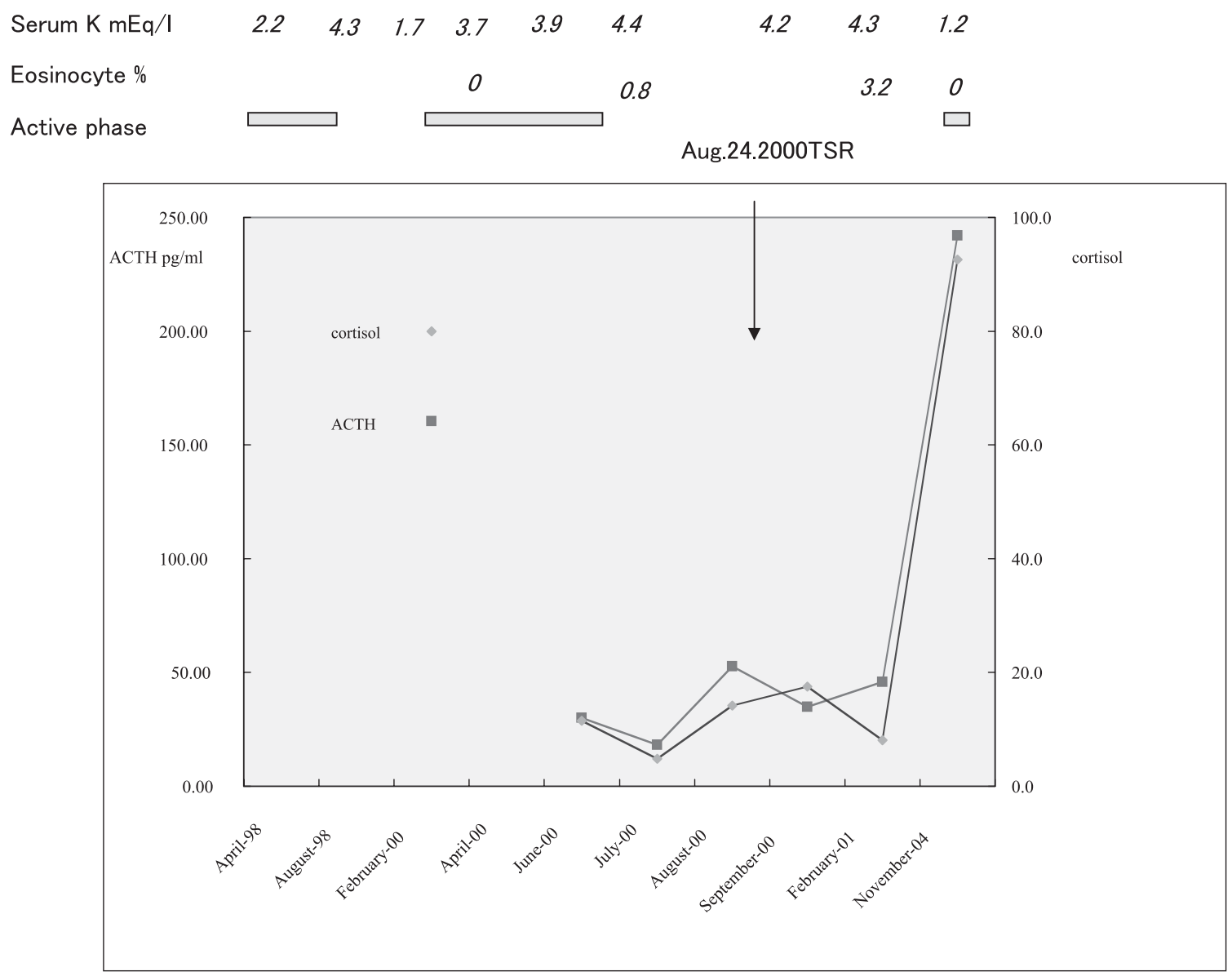

Fig. 3. Clinical course of the patient

studies including $\mathrm{CRH}$ or dexamethasone loading test and studies of diurnal rhythm of ACTH and cortisol were not performed in that postoperative period.

Repeated abnormal secretion of ACTH and cortisol, and repeated deterioration and improvement of clinical symptoms suggested the diagnosis of cyclic Cushing's disease.

In February, 2001, the patient was hospitalized for endocrinological evaluation. Plasma ACTH and serum cortisol levels were $45.8 \mathrm{pg} / \mathrm{ml}$ and $8.1 \mu \mathrm{g} / \mathrm{dl}$, respectively. Urinary 17-OHCS and free cortisol were $4 \mathrm{mg} /$ day and $56.6 \mu \mathrm{g} /$ day. Serum potassium level was $4.3 \mathrm{mEq} / \mathrm{l}$. Percentage of Eo in WBC count was 3.2\%. Diurnal rhythm of ACTH and cortisol was observed. After CRH stimulation, basal/peak plasma ACTH and serum cortisol values were $43.7 / 79.0 \mathrm{pg} / \mathrm{ml}(15 \mathrm{~min})$, and 7.5/12.9 $\mu \mathrm{g} / \mathrm{dl}(30 \mathrm{~min})$, respectively. Overnight dexamethasone test suppressed ACTH and cortisol levels to $15.7 \mathrm{pg} / \mathrm{ml}$ and $1.3 \mu \mathrm{g} / \mathrm{dl}$ (1 mg dexamethasone) and $11.2 \mathrm{pg} / \mathrm{ml}$ and $1.7 \mu \mathrm{g} / \mathrm{dl}$ (8 $\mathrm{mg}$ dexamethasone).
These results suggested that the patient was in remission phase of cyclic Cushing's disease.

However, in November 2004, the patient was hospitalized again with depressive state. Plasma ACTH and serum cortisol levels were remarkably elevated to be $242 \mathrm{pg} / \mathrm{ml}$ and $92.6 \mu \mathrm{g} / \mathrm{dl}$, respectively. Serum potassium level was $1.2 \mathrm{mEq} / \mathrm{l}$, and percentage of Eo in WBC count was $0 \%$. MRI did not disclose the recurrence of pituitary adenoma. The patient died due to rectal ulcer and ensuing multiple organ failure. The clinical course of the patient is presented in Fig. 3.

\section{Discussion}

Cyclic Cushing's disease was first reported in 1973 by Brown et al. [1], and since then 42 patients with cyclic Cushing's disease have been reported in the literature [1-37]. The possible causes of periodicity of cortisol were reported to be infarcts [5], partial necrosis 
[8] or calcification [12] of the tumor, or patient stress [15]; however, the precise mechanism is still unclear. The fluctuation of cortisol and ACTH secretion makes it difficult to establish the diagnosis of cyclic Cushing's disease, especially in the remission phase. Transsphenoidal surgery is not effective in the treatment of this disease $[3,14]$, and the cure rate is only $25 \%$ and recurrence rate is $63 \%$ [28].

A typical cyclic Cushing's disease has characteristic endocrinological features: 1) serum cortisol is not suppressed by high dose administration of dexamethasone [1-3, 9-12, 16, 25]; 2) plasma ACTH elevation is not blunted by an intravenous administration of CRH [15, 17, 21, 22]. These endocrinological features were observed also in the present case. The percentage of Eo in WBC count correlated well with the activity of the disease.

In the 42 reported cases of cyclic Cushing's disease, neuroimaging studies were carried out in 32 (76.2\%) cases. In these 32 cases, neuroimaging studies including computed tomography (CT) scan or MRI revealed the presence of an adenoma in $14(43.8 \%)$ cases. In 17 cases with MRI studies, an adenoma was identified in 8 $(47.1 \%)$ cases. Therefore, even the most sophisticated neuroimaging studies can only disclose the presence of a pituitary adenoma in less than half of patients with cyclic Cushing's disease. The alteration of the tumor size between the active and remission phases has not been reported in the literature. Moreover, selective venous sampling was carried out in 10 cases out of the 42 reported cases. In $6(60 \%)$ cases, the positive $\mathrm{C} / \mathrm{P}$ ratio of ACTH was observed. Among these 6 cases, only 1 patient had the positive C/P ratio of ACTH in the remission phase of cyclic Cushing's disease. In addition, in 2 cases with active phase of cyclic Cushing's disease, positive findings were not obtained in selective venous sampling study of ACTH. Thus, in selective venous sampling study of $\mathrm{ACTH}$, the successful identification of $\mathrm{ACTH}$ production from a pituitary adenoma with cyclic Cushing's disease is a very rare event.

The present case included very interesting and significant issues of endocrinological and neuroimaging studies. First, MRI study detected the presence of an adenoma, and secondly, selective venous sampling in the cavernous sinus disclosed the hypersecretion of ACTH even in the remission phase. These neuroimaging and endocrinological studies were helpful for the diagnosis.

Another interesting issue is noted in the present case: the disease was in the long-term remission phase after transsphenoidal surgery, although in general the recurrence rate is high in this clinical entity. The patient was in the remission phase for nearly 4 years and 3 months postoperatively. It is difficult to determine whether the long-term remission is due to successful surgery or is merely a prolongation of remission period; however, this long postsurgical period of remission is noteworthy.

In conclusion, even in the remission phase of cyclic Cushing's disease, meticulous endocrinological and neuroimaging examinations can disclose the presence of a pituitary adenoma, which is worth being treated surgically.

\section{References}

1. Brown RD, Van Loon GR, Orth DN, Liddle GW (1973) Cushing's disease with periodic hormonogenesis: one explanation for paradoxical response to dexamethasone. J Clin Endocrinol Metab 36: 445-451.

2. Liberman B, Wajchenberg BL, Tambascia MA, Mesquita CH (1976) Periodic remission in Cushing's disease with paradoxical dexamethasone response: an expression of periodic hormonogenesis. J Clin Endocrinol Metab 43: 913-918.

3. Oates TW, McCourt JP, Friedman WA, Agee OF, Rhoton AL, Thomas WC Jr (1979) Cushing's disease with cyclic hormonogenesis and diabetes insipidus. Neurosurgery 5: 598-603

4. Bochner F, Burke CJ, Lloyd HM, Nurnberg BI (1979) Intermittent Cushing's disease. Am J Med 67: 507-510.
5. Scott RS, Espiner EA, Donald RA (1979) Intermittent Cushing's disease with spontaneous remission. Clin Endocrinol (Oxf) 11: 561-566.

6. Jordan RM, Ramos-Gabatin A, Kendall JW, Gaudette D, Walls RC (1982) Dynamics of adrenocorticotropin (ACTH) secretion in cyclic Cushing's syndrome: evidence for more than one abnormal ACTH biorhythm. $J$ Clin Endocrinol Metab 55: 531-537.

7. Sakiyama R, Ashcraft MW, Van Herle AJ (1984) Cyclic Cushing's syndrome. Am J Med 77: 944-946.

8. Schweikert HU, Fehm HL, Fahlbusch R, Martin R, Kolloch R, Higuchi M, Kruck F (1985) Cyclic Cushing's syndrome combined with cortisol suppressible, dexamethasone non-suppressible ACTH secretion: a new variant of Cushing's syndrome. Acta Endocrinol 
(Copenh) 110: 289-295.

9. Atkinson $\mathrm{AB}$, Chestnutt A, Crothers E, Woods R, Weaver JA, Kennedy L, Sheridan B (1985) Cyclical Cushing's disease: two distinct rhythms in a patient with a basophil adenoma. J Clin Endocrinol Metab 60: $328-332$.

10. Atkinson AB, Kennedy AL, Carson DJ, Hadden DR, Weaver JA, Sheridan B (1985) Five cases of cyclical Cushing's syndrome. $\mathrm{Br}$ Med J (Clin Res Ed) 291: 1453-1457.

11. De Feo ML, Bonfanti L, Romano S, Fusi S, Giusti G, Messeri G, Forti G (1987) Cyclical Cushing's disease: report of a case cured by conventional cobaltotherapy. J Endocrinol Invest 10: 89-93.

12. La Civita KA, McDonald S, Jacobson J (1989) Cyclic Cushing's disease in association with a pituitary stone. South Med J 82: 1174-1176.

13. Wickus GG, Pagliara AS, Caplan RH (1989) Spurious elevation of plasma immunoreactive adrenocorticotropic hormone in cyclic Cushing's syndrome. Arch Pathol Lab Med 113: 797-799.

14. Beckers A, Stevenaert A, Pirens G, Flandroy P, Sulon J, Hennen G (1990) Cyclical Cushing's disease and its successful control under sodium valproate. $J$ Endocrinol Invest 13: 923-929.

15. Popovic V, Micic D, Nesovic M, Howlett T, Doniach I, Kendereski A, Djordjevic P, Manojlovic D, Micic J, Besser M (1990) Cushing's disease cycling over ten years. Exp Clin Endocrinol 96: 143-148.

16. Shapiro MS, Shenkman L (1991) Variable hormonogenesis in Cushing's syndrome. Q J Med 79: 351-363.

17. Mercado-Asis LB, Murayama M, Yamakita N, Morita H, Mune T, Yasuda K, Miura K (1991) Cortisolsuppressible dexamethasone-nonsuppressible cyclic Cushing's disease with evidence of clinical and biochemical remission with bromocriptine. Endocrinol Jpn 38: 315-324.

18. Velkeniers B, Beckers A, Stevenaert A, Smits J, Finne E, Vanhaelst L (1991) Cyclical Cushing's disease. A case report. Pathol Res Pract 187: 603-607.

19. Suzuki S, Ohase Y, Tomita A, Hirooka Y, Hara I (1981) The function of the pituitary of Cushing disease with periodic hormonogenesis. Horumon to Rinsho 29: 18 (In Japanese).

20. Sato T, Uchigata Y, Uedana N, Kita K, Suzuki Y, Hayashi S (1982) A case of periodic ACTH and ADH hypersecretion. Horumon to Rinsho 30: 24 (In Japanese).

21. Horigome I, Katushima I, Haneu K (1984) A case of cyclic Cushing's disease. Yamagata Saiseikan Med J 9: 93 (In Japanese).

22. Tanaka H, Yamauchi K, Takatuki K, Funabashi K, Mizuno S, Tomita A (1987) A case of Cushing's disease with periodic hormonogenesis with functional adenomatous thyroid tumor. Horumon to Rinsho 35: 14 (In Japanese).

23. Maeda H, Fujiwara R, Hanebuhi Y, Ikada K, Tamai T, Kishida S, Nakai T, Miyayasu S (1987) A case of
Cushing's disease with recurrence after spontaneous remission. J Jan Soc Intern Med 63: 609 (In Japanese).

24. Ishikawa A, Aizawa I, Hirooka Y, Mitsuma T, Ooga S, Wanibe H (1988) A case of Cushing's disease with periodic hormonogenesis. Folia Endocrinol Jpn 64: 778 (In Japanese).

25. Sakamaki $H$, Inoue $S$, Nagashima $K$, Tominaga $T$, Morita S, Harakawa S, Yamashita T, Okamoto S, Izumi M, Nagataki S (1989) A case of cyclic Cushing's disease with microadenoma in pituitary. Folia Endocrinol Jpn 65: 916 (In Japanese).

26. Seta T, Nagai K, Fujii M, Miwa U, Ooya T (1989) A dissected case of cyclic Cushing's disease without microadenoma in pituitary. Folia Endocrinol Jpn 65: 916 (In Japanese).

27. Shoda H, Uziwara M, Furukawa H, Satoh F, Miyazaki Y, Naruse M, Suda T, Amano K, Tsushima T, Demura H (1989) A case of cyclic Cushing's disease of giant adenoma in pituitary with periodic hormonogenesis. Folia Endocrinol Jpn 65: 916 (In Japanese).

28. Yasuda K, Miura K (1994) Unique type of Cushing's disease in clinical profile: Cyclic Cushing's syndrome and Cushing's disease with favorable outcome to a high daily dose of bromocriptine. Folia Endocrinol Jpn 70: 11 (In Japanese).

29. Adachi M, Takayanagi R, Yanase T, Sakai Y, Ikuyama S, Nakagaki H, Osamura Y, Sanno N, Nawata H (1996) Cyclic Cushing's disease in long-term remission with a daily low dose of bromocriptine. Intern Med 35: 207-211.

30. Yamaguchi K, Hashiguchi Y (2003) A significant adverse correlation between serum cortisol and TSH in a case of cyclic Cushing's disease based on a continuous three-year observation. Endocr J 50: 833-834.

31. Yasuzawa S, Toyoda N, Iwasaki M, Boku Y, Maeda A, Imai Y, Numa Y, Kawamoto K, Nishikawa M, Iwasaka H (2001) Horumon to Rinsho 49: 52-56 (In Japanese).

32. Hisada A, Usuda R, Wakaguri N, Kuwayama A, Nagai H, Kobayashi K (1997) Horumon to Rinsho 46: 36-40 (In Japanese).

33. Imamura S, Makino M, Itoh $\mathrm{Y}$, Ono $\mathrm{Y}$, Yamamoto $\mathrm{K}$, Katoh D, Fujiwara K, Hayakawa N, Suzuki A, Sawai Y, Oda N, Itoh M (2003) Horumon To Rinsho 51: 5558 (In Japanese).

34. Akashi T, Tojo Y, Isaka T, Sakamoto K, Tajima N, Kamio M (2004) ACTH RELATED PEPTIDES 15: 179-186 (In Japanese).

35. Otsuka F, Miyoshi S, Suzuki J, Inagaki K, Takeda M, Kishida M, Mimura Y, Ogura T, Kageyama J, Hashimoto K, Makino H (2004) ACTH RELATED PEPTIDES 15: 187-193 (In Japanese).

36. Miyamura N, Sonoda K, Murata Y, Yoshisato K, Furumori S, Fukushima H, Araki E (2001) Horumon to Rinsho 49: 14-20 (In Japanese).

37. Takeuchi Y, Nakamura R, Oi J, Katoh Y, Niimi M, Hattori K, Kuwayama A, Murata Y (1997) Horumon to Rinsho 46: 53-59 (In Japanese). 